\title{
"Mais um domingo no vale das lágrimas": um ensaio de análise fílmica (Luz de inverno, Ingmar Bergman, 1962)
}

\author{
Aurélio Fabrício Torres de Melo* \\ Breno Martins Campos**
}

\section{Resumo}

Este artigo reconhece que a linguagem do cinema é apropriada para a expressão da religião, bem como para fundamentar discussões a respeito dela. De modo geral, quanto à religião, apresentamos uma reflexão sobre o silêncio de Deus em contextos nos quais a morte gera angústia no ser humano. No cinema, de modo particular, escolhemos o filme Luz de inverno como nosso objeto de estudo. Na primeira subseção, oferecemos uma breve descrição conceitual e cronológica da morte no Ocidente, e uma brevíssima história do cinema (com a intenção de inserir Luz de inverno numa cena mais ampla); na segunda, fazemos uma análise fílmica, com o propósito de entender o que a narrativa tem a dizer. Como resultado, deparamo-nos com um roteiro em que todas as personagens experimentam um momento de angústia existencial profunda, uma crise de fé em face do silêncio de Deus, de modo que a vida se compara a um vale de morte e lágrimas. O surpreendente - eis nossa hipótese - é que o silêncio de Deus é quebrado não no púlpito nem no altar, mas, antes, a voz divina se faz ecoar dentro da sacristia.

Palavras-chave: Religião; Linguagem; Morte; Cinema; Ingmar Bergman

* Graduação em Psicologia, doutorado em Psicologia pela USP, pós-doutorado em Ciências da Religião pela PUC-Campinas (em andamento), e-mail: melo.psicologo@gmail.com, currículo Lattes: http://lattes.cnpq.br/0258571885050305.

** Graduação em Teologia e Ciências Sociais, doutorado em Ciências Sociais pela PUC-SP, membro do Corpo Docente Permanente do Programa de Pós-Graduação em Ciências da Religião (PUC-Campinas), e-mail: brenomartinscampos@gmail.com, currículo Lattes: http://lattes.cnpq.br/6935599495762856. 


\title{
"Another Sunday in the Valley of Tears": an essay on film analysis (Winter Light, Ingmar Bergman, 1962)
}

\begin{abstract}
This article recognizes that the language of cinema is appropriate for the expression of religion and supporting discussions about it. As for religion, in general, we present a reflection on the silence of God in contexts where death generates anguish in human beings. In particular, we chose the film Winter Light (Ingmar Bergman) as our object of study. In the first subsection, we offer a brief conceptual and chronological description of death in the West and a very brief history of cinema (to contextualize Winter Light into a broader film studies background); and, in the second, we carry out a film analysis, intending to understand what the narrative has to say. As a result, we are faced with a script in which all characters experience a moment of deep existential anguish, a crisis of faith in the face of God's silence, so that life is compared to a valley of death and tears. The surprising thing - this is our hypothesis - is that the silence of God is broken not on the pulpit or the altar, but the divine voice is echoed inside the sacristy.

Keywords: Religion; Language; Death; Cinema; Ingmar Bergman
\end{abstract}

\section{"Otro domingo en el valle de las lágrimas": ensayo de análisis fílmico (Luz de invierno, Ingmar Bergman, 1962)}

\section{Resumen}

Este artículo reconoce que el lenguaje del cine es apropiado para la expresión de la religión, así como para basar las discusiones sobre ella. En cuanto a la religión, en general, presentamos una reflexión sobre el silencio de Dios en contextos donde la muerte genera angustia en los seres humanos. En el cine, en particular, elegimos la película Luz de invierno (Ingmar Bergman) como nuestro objeto de estudio. En la primera subsección, ofrecemos una breve descripción conceptual y cronológica de la muerte en Occidente, y una muy breve historia del cine (con el objetivo de insertar Luz de invierno en un escenario más amplio); y, en el segundo, realizamos un análisis fílmico, con el objetivo de comprender lo que la narrativa tiene que decir. Como resultado, nos encontramos ante un guion en el que todos los personajes enfrentan un momento de profunda angustia existencial, una crisis de fe ante el silencio de Dios, por lo que la vida se compara con un valle de muerte y lágrimas. Lo sorprendente - he aquí nuestra hipótesis - es que el silencio de Dios no se rompe en el púlpito ni en el altar, sino que la voz se hace eco dentro de la sacristía.

Palabras clave: Religión; Lenguaje; Muerte; Cine; Ingmar Bergman

\section{Introdução}

Título deste artigo, a frase "mais um domingo no vale das lágrimas" (LUZ de inverno, 2019, 23'06") foi dirigida, de modo irônico mas assertivo, ao viúvo pastor Tomas por sua amante Märta, poucos momentos depois de ele haver celebrado um culto (ou missa) - com presença muito reduzida de 
"Mais um domingo no vale das lágrimas": um ensaio 141 de análise fílmica (Luz de inverno, Ingmar Bergman, 1962)

fiéis -, conversado com algumas poucas pessoas e executado outras tarefas ministeriais de menor importância. Tudo cumprido quase mecanicamente e de forma pesarosa por um sofrido e combalido Tomas. Entretanto, não seria desajuizado de nossa parte se déssemos outro título ao artigo, por exemplo, "O silêncio de Deus em face da angústia e da morte". A opção adotada nasceu do fato de toda a história de Luz de inverno se passar num único e longo domingo, arrastado mesmo, pois o filme de forma proposital tem um ritmo lento.

Simbolicamente, estamos diante de toda uma vida (de cada uma e de todas as personagens) contida e contada num único dia, justamente o domingo ou dia do sol - no qual, na verdade, nem tudo é luz, pois as sombras são uma constante no filme - ou, ainda, dia do Senhor, em sua forma cristianizada. Enquanto se faz a oração do "pai-nosso" (também conhecido como "oração dominical") dentro do templo, a câmera passeia pelo ambiente externo: nenhum movimento, exceto o da corredeira das águas, a indicar certa fluidez. No transcurso das horas - e registramos que o relógio, seus movimentos e sons são presença importante no que nos diz. o filme -, o tema que atravessa aquele domingo está mesmo vinculado ao silêncio de Deus em face da morte e da angústia humana. Trata-se, portanto, de um longo domingo de vida e morte (ou vice-versa), permeado pela dúvida como elemento constituinte da fé.

Ainda que filmes não sejam propriamente aquilo que deles se fala, no texto da contracapa da caixa (box) de A trilogia do silêncio (2019), utilizada por nós como artefato material de pesquisa, pode ser lida a seguinte informação: "No início dos anos 60, durante a Guerra Fria, Ingmar Bergman realizou três dramas sobre a crise de fé do homem moderno, criando o que seria chamado pela crítica de $A$ trilogia do silêncio ou $A$ Trilogia da fê", constituída dos filmes Através de um espelho, de 1961 (vencedor do Oscar de Melhor Filme Estrangeiro em 1962), Luz de inverno, de 1962, e O silêncio, de 1963. Na sinopse de Luz de inverno, filme escolhido para nossa análise, são apresentadas as palavras e ideias que seguem:

Após ler nos jornais que a China tem a bomba atômica e pretende usá-la, um pescador vai à igreja, buscando palavras de conforto e consolo do pastor. Porém, este não consegue ajudá-lo, pois está passando por uma crise de fé, temendo o apocalipse nuclear. Dialogando com O Diário de um Pároco de Aldeia (1950 [1951]), de Robert Bresson, Bergman tece uma amarga reflexão. (LUZ de inverno, 2019). 
O texto é um pouco ambíguo, pois quem está em crise por causa de uma potencial ou eminente hecatombe nuclear é o pescador Jonas, e não o pastor (pelo menos, não diretamente). Destacamos, entretanto, os comentários referentes a Bresson; o mencionado filme do cineasta francês - cuja versão utilizada por nós foi traduzida por Diário de um padre (s.d.) - teve o roteiro adaptado do livro Diário de um pároco de aldeia, de Georges Bernanos, publicado originalmente em 1936 (a edição utilizada por nós é de 2011).

A primeira parte da obra de Bernanos é uma apresentação do próprio diário escrito pelo pároco, a segunda analisa o triunfo da sua fé mas, ao mesmo tempo, constata o seu fracasso como homem e sua distância da comunidade, isto é, sua total rejeição na aldeia. Já a terceira parte narra sua morte, seu sacrifício, que aparece aqui com as cores marcantes de uma vida que relembra o martírio e todo o seu rico significado no cristianismo. (PAULA, p. 102, 2011).

Na comunidade do jovem e anônimo pároco de Bernanos - e, por extensão, de Bresson -, ambientada em Ambricourt, cujas celebrações religiosas são pouco concorridas, "ocorrem mortes naturais, suicídios e aquelas mortes nas quais ficamos em dúvida se foram naturais ou não. Curiosamente a dúvida acompanha tudo, até mesmo a hora da morte" (PAULA, p. 103, 2011). Não há como negar que se esforçava o padre, mesmo que sem êxito, para manter viva, primeiramente, sua própria fé e, depois, a de seus paroquianos - num momento em que o silêncio de Deus se apresentava ora como sintoma moderno da morte divina, ora como sensação da angústia humana ou da indiferença pela vida.

Para nós, a maior lição da obra literária de Bernanos, adaptada para o cinema por Bresson, está localizada na dinâmica entre a palavra (ou as palavras) e o silêncio. "Uma das mais incompreensíveis desgraças dos homens está em que devem confiar o que há de mais precioso a essa coisa, meu Deus, tão instável, tão plástica - a palavra!" (BERNANOS, 2011, p. 43). O pároco, ele mesmo, registra em seu diário, num momento de angústia da mente e dos sentidos: "Tumulto de ideias, de imagens, de palavras. A alma se cala. Deus se cala. Silêncio" (BERNANOS, 2011, p. 43). Ainda que em plena angústia (pessoal ou comunitária, local ou global), o silêncio de Deus - seja como experiência vivida, seja como metáfora da realidade - não deve se transformar em apropriação monossêmica e fanática da palavra por nenhuma pessoa ou grupo. A plasticidade da palavra, que é também marca indelével de sua instabilidade - e fragilidade, por que não? - inclui o silêncio, mesmo que insuportável. 
"Mais um domingo no vale das lágrimas": um ensaio 143 de análise fílmica (Luz de inverno, Ingmar Bergman, 1962)

Pretendemos identificar no filme Luz de Inverno - ambientado em contexto protestante luterano (com diferenças e também aproximações em relação ao do pároco católico-romano de Bernanos e Bresson) - teses ou discursos fílmicos acerca do silêncio de Deus em face da morte e da angústia humana, bem como frente ao desamparo e à crise de fé (individual e coletiva). Tanto no contexto católico do pároco francês como no ambiente protestante do pastor sueco, as igrejas estão vazias e o exercício religioso, para a maior parte das pessoas, não passa de mera obrigação ou formalidade.

Conforme propõem Jacques Aumont e Michel Marie sobre a análise do tema como elemento da forma, metodologicamente, consideramos um filme como narrativa, ou seja, entendemos que "não existe conteúdo independente da forma na qual é exprimido" (2009, p. 84). E das três indagações que Richard Monod (apud AUMONT; MARIE, 2009) lança ao exame analítico de textos teatrais - (1) de que falam? (temas), (2) o que contam? (fábulas) e (3) o que dizem? (discursos ou teses) -, interessa-nos transpor para o cinema (e, particularmente, para o filme Luz de inverno) o terceiro dos questionamentos.

Por conseguinte, fazemos a análise do filme como narrativa, especialmente quanto às teses e discursos que sustenta, e procuramos respostas, ainda que inconclusas, à terceira indagação de Monod (apud AUMONT; MARIE, 2009) - trata-se, portanto, de uma análise relacionada a nossos objetivos. No caso particular deste artigo, nossa inquietação vem das seguintes perguntas: de modo geral, o que diz Luz de inverno e, particularmente, qual discurso profere acerca do silêncio de Deus em face da morte? Asseveramos que o silêncio divino é uma constante em Luz de inverno e, com destaque, está encarnado na vida e obra do ministro religioso Tomas - que nos é apresentado em sua viuvez e falta de entusiasmo, doente do corpo e da alma.

A análise fílmica, por sua vez, é elaborada como adjuvante da interpretação temática (ou do filme como narrativa), isto é, para avaliação dos elementos que se destacam na construção das teses apresentadas pelo filme - trata-se, portanto, de uma análise relacionada a nosso método. Podemos dizer que é um processo inverso ao de assistir a um filme, trata-se de ver as partes que compõem o todo, pois, quando assistimos a um filme, sem compromisso analítico ou por entretenimento, estamos vendo o todo ou a unidade.

Segundo Francis Vanoye e Anne Goliot-Lété, a análise fílmica é, ao mesmo tempo, processo e produto da atividade de investigação: 
Analisar um filme ou um fragmento é, antes de tudo, no sentido científico do termo, assim como se analisa, por exemplo, a composição química da água, decompô-lo em seus elementos constitutivos. É despedaçar, descosturar, desunir, extrair, separar, destacar e denominar materiais que não se percebem isoladamente "a olho nu", uma vez que o filme é tomado pela totalidade. Parte-se, portanto, do texto fílmico para "desconstruí-lo" e obter um conjunto de elementos distintos do próprio filme. [...] Uma segunda fase consiste, em seguida, em estabelecer elos entre esses elementos isolados, em compreender em como eles se associam e se tornam cúmplices para fazer surgir um todo significante: reconstruir um filme ou o fragmento. (1994, p. 15).

Entretanto, antes da análise propriamente dita de Luz de inverno, na primeira subseção deste artigo, reportamo-nos a Philippe Ariès (1981) como referencial para o debate da temática da morte, juntamente com a contribuição da tanatologia, tomando a obra de Maria Júlia Kovács (2003) como uma abordagem psicológica em diálogo com a historiografia de Ariès. Em seguida, apresentamos uma brevíssima (e arbitrária) história do cinema, com o objetivo de localizar Ingmar Berman numa certa linha do tempo da sétima arte.

Na construção da argumentação, já na segunda subseção, nossa análise do filme Luz de inverno, orientada metodologicamente por Aumont e Marie (2009), visa a explorar a tese que ele sustenta acerca do silêncio de Deus em face da morte - ou seja, o que tem ele a dizer sobre uma temática tão humana. Ademais, a análise fílmica se incorpora justamente como recurso metodológico para identificarmos os elementos de significação (som, fotografia, montagem, movimentos de câmera etc.), indispensáveis à construção da narrativa (VANOYE; GOLIOT-LÉTÉ, 1994).

Segundo o pressuposto filosófico de André Comte-Sponville (2002) de que a morte constitui, para o pensamento, um objeto impossível e necessário, perguntamo-nos se o cinema, com sua linguagem específica, poderia revelar mais discursos sobre a morte na contemporaneidade do que outros construtos culturais. Antes de tudo, entretanto, precisamos conhecer mais sobre a questão da morte. Afinal de contas, tem razão Marcio Gimenes de Paula que se encontra, mesmo que implicitamente, com Albert Camus (e o mito de Sísifo) em Luz de inverno - ao nos trazer algo inquietante à memória: "a única pergunta relevante filosoficamente é se a vida deve ou não ser vivida" (p. 106, 2011). 
"Mais um domingo no vale das lágrimas": um ensaio 145 de análise fílmica (Luz de inverno, Ingmar Bergman, 1962)

\section{Sobre morte e cinema ${ }^{1}$}

Ariès (1981) descreve as diversas relações do ser humano com a morte, da Idade Média ao século XX, isto é, da morte domada ou aceita como destino natural à morte invertida, ocultada e negada, passando pela morte romântica e desejada. $\mathrm{Na}$ alta Idade Média, a morte era regulamentada por um ritual costumeiro, nada traiçoeira na forma de se apoderar das pessoas; pelo contrário, oferecia certo tempo para ser percebida - como se o moribundo se entregasse à morte. À mentalidade da época, a morte repentina não era bem-vista (porque creditada à cólera de Deus). As pestes, por exemplo, eram tidas como castigo divino; e, frente aos males do corpo, restava rezar.

É na modernidade que o ser humano, paulatinamente, passa a legislar sobre o corpo. Ao mesmo tempo, Deus vai sendo deslocado do mundo para o céu (por mecanismos próprios da modernidade). A ciência emerge com promessas de vitória da humanidade sobre a natureza - como se tal disjunção (humanidade e natureza) pudesse ser empiricamente sustentável ou razoável -, ao suprir as necessidades básicas do ser humano, por exemplo, o controle de pestes e o combate aos males do corpo. De terreno do sagrado, o corpo e a morte passam a objeto da medicina. Sintoma da dessacralização do mundo, o ser humano passa a ser o objeto de seu próprio encantamento na arte, na filosofia, na teologia, na ciência.

Como consequência, no século XIX, a confusão entre morte e vida (característica dos séculos XVII e XVIII) tende a indicar ou reforçar a noção da morte como separação entre o corpo e a alma. A pessoa morta não mais dorme ou repousa, como o imaginário anterior sustentava, mas pode estar sofrendo em algum lugar. É preciso rezar por ela, comunicar-se com ela, saber como está. A dor da separação entre vivos e mortos precisa ser mitigada. O século XIX foi também marcado pelo romantismo; tão em voga nos séculos XVII e XVIII, a razão dá lugar a paixões, e a morte se torna sedutora. Sendo o amor maior que a morte, os amantes poderiam se encontrar no além, portanto, nada mais charmoso do que se retirar da vida amando - ou para escapar do envelhecimento.

O crescimento das cidades e a industrialização modificaram o cotidiano e uma nova forma de encarar a morte emergiu, despontando plenamente no século XX. O livro A morte de Ivan Ilitch de Liev Tolstói - original de 1886 pode ser considerada a obra literária que antecipa a relação do ser humano

Texto retirado, pois indica autoria! 
com a morte no século XX. Ivan Ilitch está doente e vai morrer, de modo sôfrego e prolongado. Os familiares procuram negar a inevitabilidade de sua morte, assim, o único assunto possível é a doença - a morte é ocultada pela doença. Particularmente, a morte de Ivan Ilitch é assunto do médico, como modelo típico-ideal da morte no século XX: invertida, segundo expressão de Ariès (1981), porque, ao contrário de tudo que a precedera, passa a ser escondida de todos ${ }^{2}$. Longe de ser o destino da vida, a morte é encarada hoje como acidente de percurso. Talvez estejamos inconformados com a morte como nunca antes na história do Ocidente.

Na sociologia, por exemplo, Zygmunt Bauman enxerga na atualidade a banalização como forma de invisibilização da morte: "Assim banalizada, a morte torna-se demasiado habitual para ser notada e excessivamente habitual para despertar emoções intensas" (1998, p. 199). Embora a obra original de Bauman seja de 1997 (a edição brasileira de O mal-estar da pós-modernidade que utilizamos foi publicada no ano seguinte, em 1998) - de fins do século XX, portanto -, ela é capaz de captar os sentidos da morte na transição para o século XXI, e que permanecem em plena efetividade, ou seja, transformando a morte de pessoas em número de mortos.

Também a psicologia tem se apropriado do tema da morte na contemporaneidade, a fim de compreender suas repercussões subjetivas. Destacamos, aqui, as contribuições da tanatologia no esforço de reumanização da morte, ou seja, de resgate do lugar que ela já ocupou noutros tempos, o de condição inerente à vida. Em diálogo com Ariès - e por ampliação cronológica e conceitual da obra dele -, Kovács (2003) acrescenta um retrato da morte neste início de século, o da morte escancarada, referindo-se à morte violenta nos espaços público e privado, que invade nossas vidas de maneira brusca, repentina e inesperada, notadamente, pelos meios de comunicação.

Os tempos pandêmicos que vivemos confirmam, a seu próprio modo, o escancaramento - e para algumas pessoas (sem empatia) também a banalização - da morte nos espaços público e privado, com várias de suas cenas veiculadas, ao vivo, por horas a fio. É claro que não estavam previstas em nenhuma obra sobre o tema da morte, antes de 2020, as consequências

\footnotetext{
2 A indiferença em relação à morte (negação, ocultamento, repressão) - a preferência por não se falar no tema -, por óbvio, tornou-se impossível nos últimos meses (2020 e 2021). A pandemia de Covid-19 mudou o estatuto da morte em nossa realidade, tempos difíceis (ou sombrios) em que até mesmo o recurso ao castigo dos céus foi (novamente) acessado por algumas mentalidades fanáticas para explicar a doença.
} 
"Mais um domingo no vale das lágrimas": um ensaio 147 de análise fílmica (Luz de inverno, Ingmar Bergman, 1962)

da pandemia pelo novo coronavírus no mundo e, particularmente, no Brasil. Byung-Chul Han, por exemplo, abre o seu conhecido livro Sociedade do cansaço (original de 2010), com a seguinte afirmação:

Cada época possui suas enfermidades fundamentais. Desse modo, temos uma época bacteriológica, que chegou ao seu fim com a descoberta dos antibióticos. Apesar do medo imenso que temos hoje de uma pandemia gripal, não vivemos numa época viral. Graças à técnica imunológica, já deixamos para trás essa época. Visto a partir da perspectiva patológica, o começo do século XXI não é definido como bacteriológico nem viral, mas neuronal. (2016, p. 7).

É claro que permanece a relevância do livro de Byung-Chul Han a respeito do cansaço a que todos estamos submetidos no mundo contemporâneo. O inusitado da citação anterior só confirma como multifacetada é a questão da morte, e que sua compreensão exige conhecimento de mais de um (ou alguns) de seus aspectos - isto é, a complexidade do assunto tem de ser tratada de modo interdisciplinar. Não queremos arriscar, ainda no calor da hora, uma nova classificação ou nomeação para a morte nos tempos pandêmicos que estamos vivendo, mas, sim, retomar a temática da angústia humana decorrente do silêncio de Deus em face da morte, também nos tempos sombrios em que nos encontramos. Daí que tenhamos escolhido a arte (o cinema, particularmente) como linguagem para a reflexão, em franco diálogo com saberes de outras disciplinas. "A 'especificidade' do cinema é a presença de uma linguagem que quer se tornar arte no seio de uma arte que, por sua vez, quer se tornar linguagem" (METZ, 1977, p. 76).

Marcel Martin (2007) vem ao nosso encontro e explica a religação da imagem do objeto com o próprio objeto, ao afirmar que a primeira (a imagem) surge, tecnicamente, por impressão do segundo (o objeto). Quer dizer, a fotografia resulta da luz refletida pelo objeto, portanto, é sempre o objeto que imprime sua imagem. De modo que a morte retratada no cinema no caso deste artigo, um convite a refletir sobre o silêncio de Deus - não é a mesma morte do cotidiano das pessoas ou do nosso existir. Em contrapartida, há no cinema uma imagem da morte que, do ponto de vista da linguagem cinematográfica, é a própria morte - pois cinema é imagem.

Foi em 1896 que os irmãos Auguste e Louis Lumière exibiram, pela primeira vez, um filme animado para espectadores. "Os irmãos franceses acreditavam que seu trabalho com imagens animadas seria direcionado para a 
pesquisa científica e não para a criação de uma indústria do entretenimento" (TURNER, 1997, p. 11). Equivocaram-se em seu prognóstico e o cinema seguiu suas próprias trilhas. Vanoye e Goliot-Lété (1994), por sua vez, descrevem a história das formas fílmicas pela perspectiva técnica do cinema: após os filmes de um único plano, destacam-se aqueles marcados pela não continuidade, a não homogeneidade, o não remate e a não linearidade.

A continuidade narrativa, ainda segundo Vanoye e Goliot-Lété (1994), chega com David Llewelyn Wark Griffith e com o modelo de produção dos filmes dos grandes estúdios hollywoodianos: a homogeneização dos significados visual e narrativo, assim como do significante audiovisual. A linearização (ou a vinculação de um plano ao plano seguinte) é outro dos princípios da continuidade narrativa. Mais do que um modo de narrativa, o cinema estadunidense impõe uma estética na produção de filmes na segunda década do século passado. No mesmo período, a então União Soviética é centro de uma das tendências rebeldes ao classicismo, especialmente pelo interesse do Estado em usar o cinema como meio de ensino e propaganda.

Vanoye e Goliot-Lété (1994) também nos lembram que no universo do cinema a reação ao imperialismo estadunidense não se restringiu aos exsoviéticos. Os franceses, em sua primeira vanguarda (impressionismo), ainda na década de 1920, empenharam-se em libertar seu cinema nacional da submissão ao teatro e ao romance, ou seja, da obrigatoriedade de contar histórias. A segunda vanguarda (dadaísmo e surrealismo) caracterizou-se por composições visuais centradas em formas abstratas, em movimento e ritmos puros.

Quanto ao cinema francês, fazemos uma necessária interlocução, segundo o escopo deste artigo, com a obra de Robert Bresson, cuja fase mais minimalista foi inaugurada pelo filme Diário de um padre (Journal d'un Curé de Campagne).

Foi feliz Bresson ao levar à tela o romance de Bernanos, em razão de sua interioridade e de seu patético conteúdo. Bresson procura a mais total fidelidade ao romance. O filme é considerado um caso singular de fidelidade cinematográfica a um texto literário. [...] Mas o filme é todo seu, sem servilismo ao romance. Rege-se totalmente por princípios cinematográficos. Usa dos meios próprios do cinema para fazer de uma obra-prima da literatura uma obra-prima do cinema. Planos numerosos e curtos, ausência quase total de planos de conjunto, dando proeminência aos rostos humanos e objetos. $\mathrm{O}$ único movimento que se nota é o movimento da sucessão de planos e do ritmo. O conteúdo é expresso magnificamente pela forma. (LEMOS FILHO, p. 26-27, 1992). 
"Mais um domingo no vale das lágrimas": um ensaio 149 de análise fílmica (Luz de inverno, Ingmar Bergman, 1962)

De um lado, podemos considerar que os movimentos estéticos no cinema - muitos dos quais nem sequer mencionamos aqui - foram, de fato, respostas a seu próprio tempo; mas, de outro, que se infiltraram também no cinema clássico e não cessaram de influenciar posteriormente todo o cinema, demonstrando as características do filme moderno. Em meados do século passado, por exemplo, uma forma de cinema exemplar nasceu na Suécia, pelo contrato de trabalho da Svensk Filmindustri com o então escritor de peças de teatro Ingmar Bergman. Inicialmente, a partir de 1941, como roteirista de romances e novelas e, depois, como continuísta nos anos 1944 e 1945, Bergman estreou na direção com o filme Crise (1945). Fazemos notar, portanto, que se trata de um período marcado pela Segunda Guerra Mundial, pelo pós-Guerra e pela consequente Guerra Fria. Quanto à religião, vivia a Europa um período em que boa parte do protestantismo se achava em frangalhos - em face dos desafios do século (em mais de um sentido). Bergman dirigiu muitos filmes, até chegar em 1962 a Luz de Inverno, disposto ou classificado por ele mesmo em sua fotobiografia (intitulada Imagens) no capítulo "CRENÇA/DESCRENÇA", ao lado dos filmes O Sétimo Selo e Através de um espelho (BERGMAN, 1996).

Ao relacionarmos Bergman com o tema da morte e da angústia dela decorrente - na dialogia entre crença e descrença (ou vice-versa) -, não podemos deixar de mencionar um dos mais aclamados filmes da história do cinema, O Sétimo Selo (de 1956/1957): "Foi realizado em 35 dias e é um dos poucos filmes que me acalenta o coração" (BERGMAN, 1996, p. 233). A tese central de $O$ sétimo selo, inclusive por semelhança das narrativas, retorna em Luz de inverno, no qual Bergman discursa novamente sobre a morte - desta vez, associada ao silêncio de Deus e sob influência, como já apontamos, do Diário de um pároco de aldeia, de Bernanos na literatura e de Bresson no cinema. Ademais, registramos a irredutível percepção de que, do ponto de vista da análise fílmica, O sétimo selo é mais rico e técnico do que Luz de inverno.

Digno de nota é o registro da opinião de Bergman a respeito do próprio filme: "Decorrido um quarto de século, é para mim ainda um prazer ver Luz de Inverno. Constato que neste filme nada se perdeu ou corroeu" (BERGMAN, 1996, p. 255)³. Podemos acrescentar, ainda hoje, também

\footnotetext{
"Além disso, cabe ressaltar que esse era um de seus filmes prediletos, tendo conotação fortemente biográfica. Bergman, inclusive, assume que aspectos de sua trajetória biográfica se tornaram mais claros para ele mesmo a partir da realização desse filme". (PIEPER, p. 276, 2017).
} 
nós sentimos o mesmo prazer. Quanto à narrativa não haver se perdido ou corroído, concordamos com Bergman ainda mais hoje (por acréscimo de nossa realidade à relevância do filme), pois o mundo parece estar diante de um Deus silente em tempos de morte escancarada pela pandemia - tanto para os que creem como para os que não creem.

\section{Sobre Luz de inverno ${ }^{4}$}

Pela já citada sinopse de Luz de inverno disponibilizada pela distribuidora Versátil, que apresenta a narrativa na perspectiva do pescador Jonas, podese ficar com a impressão de que ele é o protagonista da narrativa fílmica. Entretanto, arriscamos propor que a personagem central é a própria comunidade - os comungantes ou partícipes da eucaristia ${ }^{5}$ (intenção original do título sueco do filme) - e, dentro dela, o destaque está colocado evidentemente na figura do pastor Tomas, numa condição ou posição de quem de Deus só percebe o silêncio. Ainda que o título Nattvardsgästerna não ofereça indícios da questão central da narrativa - que, para nós, é o silêncio de Deus num contexto humano de morte e angústia -, trata-se de uma escolha do diretor. Por sua vez, Luz de Inverno, que ganhou força por causa da versão estadunidense do filme (Winter Light), é um título metafórico, posterior ao momento de criação da obra e alheio à vontade do criador. Mesmo assim, Marcio Gimenes de Paula propõe uma consideração digna de nota:

Não parece fortuito, notadamente se pensarmos no contexto nórdico, que o título do filme Luz de inverno é, na verdade, uma mescla de coisas, isto é, de trevas e de luz. O rigoroso inverno no Norte também proporciona as trevas na quase totalidade do dia como também pode trazer pequenos - e valiosos - pontos de luminosidade, isto é, a luz de inverno. Quase toda a ação do

\footnotetext{
Seguem os elementos técnicos de Luz de inverno, incorporados, direta ou indiretamente, em nossa análise: (1) Ficha do filme: Produção: Allan Ekelund, 81 min, P \& B, 1962, Suécia / Lançamento: 11.02.1963 / Direção: Ingmar Bergman / Roteiro: Ingmar Bergman / Elenco: Ingrid Thulin, Gunnar Björnstrand, Gunnel Lindblom, Max Von Sydow / Direção de fotografia: Sven Nykvist / Direção de arte: Karl-Arne Bergman / Edição: Ulla Ryghe / Distribuição: Svensk Filmindustri / Idioma: sueco; (2) Ficha do DVD: Distribuição: Versátil Digital Filmes, 96 min, áudio 2.0, idioma sueco, legenda em português. Extra: Trailer de cinema; Vida e obra de Ingmar Bergman; Galeria de fotos; Menus interativos; Seleção de cenas.

5 Lembramos que a primeira cena do filme é marcada pelo pastor Tomas repetindo as palavras de Jesus na última ceia - a respeito do pão como seu corpo e do vinho como seu sangue -, aquelas mesmas que instituíram o rito da eucaristia no cristianismo ("fazei isto em memória de mim", foi o ensinamento do Cristo aos apóstolos).
} 
filme de Bergman se passa no contexto fechado da paróquia, onde a luz não parece existir plenamente ou onde ela só pode ser vista por pequenas frestas. (PAULA, p. 109, 2011).

Por conseguinte, chegamos à consideração de que a narrativa de $L u z$ de inverno está fortemente apoiada no texto fílmico e que os elementos fílmicos (câmera, som, montagem, iluminação etc.) estão a serviço do texto - isto é, os diálogos têm estatuto de centralidade. Não seria exagero, portanto, pensarmos no filme como um teatro filmado: a câmera alterna closes frontais e laterais das personagens em grande parte dos planos-sequências, de acordo com a fala de cada personagem, permitindo que cada uma se dirija direta e intimamente ao espectador. "Colabora para isso a ausência de trilha sonora, que, não sem intenção, direciona a atenção do espectador para o silêncio seja das personagens seja do próprio Deus, que tem sua existência constantemente questionada" (MEIRELES, p. 46, 2017) ${ }^{6}$. Vamos, então, tratar dos assim chamados capítulos do filme (de acordo com a seriação do DVD), mas não de todos, haja vista os recortes e o escopo deste artigo, fazendo a interpretação do filme (conteúdo) fundamentada pela análise fílmica (método).

Vista como uma apresentação ou introdução à narrativa, a cena de abertura do filme mostra o culto ou missa, e as personagens protagonistas e coadjuvantes - inclusive com a já mencionada celebração da eucaristia para a participação dos comungantes. Os planos-sequências que apresentam as personagens - ora no coletivo de modo hegemônico (plano inteiro), ora individualmente de modo singular (primeiro e primeiríssimo planos) descrevem uma liturgia que propõe certa igualdade entre os seres humanos, mas que não dá (mais) conta da subjetividade religiosa ou de uma religiosidade tornada subjetiva. Cada personagem com sua singularidade corpórea sugere uma motivação ou, sobretudo, uma desmotivação particular para estar ali. Um significativo detalhe: a única criança presente no contexto de culto está distraída e termina a celebração dormindo num dos bancos do templo. Impossível não nos lembrarmos do pároco de aldeia (Bernanos e Bresson), em sua luta inglória para se fazer respeitado na paróquia e para os fiéis se reaproximarem sinceramente da religiosidade.

\footnotetext{
6 Outra causa para explicar o tipo adotado de narrativa fílmica se localiza na irresistível associação que podemos fazer com as origens do diretor e roteirista Ingmar Bergman ligadas ao teatro (que deixamos de fora da análise do discurso fílmico por questão de método, mas que vale como evidência histórica).
} 
Em Luz de inverno, a narrativa fílmica se revela, ainda, pelo trabalho da câmera, que mostra uma igreja com poucas pessoas e muitos lugares sem ninguém. Com efeito, de acordo com a narrativa da câmera, podemos dizer que se trata de uma igreja vazia - discursivamente, uma igreja esvaziada. Para além do espaço físico da igreja, é o esvaziamento da fé que se revela simbolicamente no discurso fílmico. O pastor Tomas, em profunda crise de fé, parece estar entre a mudez de Deus e a surdez de seus fiéis.

Ao terminar o culto, Tomas e Aronsson, seu auxiliar no ato de contar as ofertas (tesoureiro), seguem para o gabinete anexo ao templo (a sacristia). Aquilo que não se fala na celebração nem no altar é falado ali. A semelhança entre teatro - de novo - e igreja não seria descabida: há um texto a ser seguido no altar e um script para todos os presentes na cena de abertura. Em contrapartida, nesse novo plano-sequência, o espectador vai conhecer os bastidores do culto e os conflitos pessoais das personagens. O sacristão Algot, pensionista da ferrovia (por sofrer de constantes dores no corpo e limitação dos movimentos) e auxiliado financeiramente pelo conselho paroquial, comenta que precisa conversar com o pastor. Sem que fosse possível naquele momento - por não haver recebido nenhuma atenção -, disse que estaria com Tomas no culto da tarde em outra comunidade (a fim de preparar o necessário para a celebração). Ocasião em que poderiam conversar com mais calma. A pequena importância que o pastor e o tesoureiro dão a Algot, por ora, é digna de registro.

Destaca-se, em seguida, o conflito do pescador Jonas Persson que, ao ler nos jornais a respeito da bomba atômica chinesa, perturba-se e passa a ter desentendimento sucessivos com a esposa Karin. Na verdade, é ela quem fala de seu marido e por ele com o pastor, enquanto o próprio Jonas se mantém em silêncio e afastado do centro da cena. Até o momento em que Tomas começa a responder e revelar sua própria dúvida e impotência perante as catástrofes do mundo. Trata-se, sobretudo, da suspeita do pescador sobre a emergência de uma nova era na história - a da possibilidade de morte de toda a humanidade. As guerras já haviam dado seu recado e as notícias das ameaças nucleares ecoavam cada vez mais. Guerras e rumores de guerras, o cenário é apocalíptico (no sentido de indicar a eminência do fim).

A câmera em plano-detalhe mostra a mão de Tomas trêmula e perdida: "Me sinto tão impotente. Não sei o que dizer. Compreendo seu desespero... mas devemos continuar vivendo", diz o pastor; e ouve de imediato, como reação de Jonas: "Por que devemos continuar vivendo?" (LUZ de inverno, 
"Mais um domingo no vale das lágrimas": um ensaio 153 de análise filmica (Luz de inverno, Ingmar Bergman, 1962)

2019, 19'03"-19'12'). Eis o mote discursivo do filme: por razões diferentes, há um paroquiano em crise existencial e um pastor em condição semelhante (sem condições, portanto, de ajudar ao próximo ou a si mesmo. Os diálogos expõem a "tese" central do discurso do filme, o que ele nos diæ: a crise da fé em face do silêncio de Deus, num contexto de eminente catástrofe mundial (morte) ou de angústia pessoal (também mortal). "É tão opressivo e Deus parece tão distante”, resume o pastor (LUZ de inverno, 2019, 18'55”).

Märta retorna à igreja para trazer algo de comer e beber ao pastor. Eles mantêm um romance conflituoso e não assumido, embora conhecido publicamente. Tomas pergunta a ela sobre o porquê de haver participado da ceia da comunhão, se não acreditava naquilo. A resposta: para ela, não se trata a eucaristia de um refeição do corpo e sangue de Cristo, mas de um banquete do amor. Mas também ela, como seu amado, sente-se incomodada e num contexto vivencial de crise. Não por causa do silêncio de Deus, que a ele tanto afetava, mas porque nunca concordara com a ideia de Tomas de que simplesmente deveriam continuar vivendo (talvez nem ele mesmo estivesse convencido de suas palavras). Ao contrário, vivia ela a reclamar da não reciprocidade de seu amor. Enfim, há um conflito em todas as personagens, oscilando entre uma dúvida arrebatadora e um dever sem sentido.

Na sequência, Tomas revê fotos de seu antigo amor - cuja morte feriu também de modo mortal a existência do próprio ministro religioso - e lê uma carta de Märta. De início, é Tomas quem segura a carta e inicia a leitura, todavia, muito rapidamente, faz-se um corte, com Märta em primeiro plano, olhando para câmera e lendo o texto para ele. Trata-se de um recurso de linguagem fílmica que visa a contar diretamente ao espectador um pouco mais sobre o protagonista. O texto é duro. Märta duvida da fé de seu amado e o enxerga como alguém envolto numa espécie de sofrimento incapacitante de viver de acordo com a doutrina religiosa e as prédicas que entrega à comunidade. Mais ainda, ela o acusa de ser incapaz de amar - e de não a respeitar em seus sentimentos e ações. Ainda assim, não cansa de declarar seu amor por ele e de fazer disso o sentido de sua vida. Märta é outra personagem em conflito existencial, mas sua angústia não diz respeito à fé em Deus. Para ela, "Deus nunca falou, pois Deus não existe. Só isso" (LUZ de inverno, 2019, 24’23”). A dúvida de Märta é se deve ou não confiar no amor.

Depois de certo tempo, conforme combinado na sacristia após o culto, volta o pescador para conversar de modo reservado com o pastor (que cochilava, debruçado em sua mesa de trabalho). Quase sem mediações, o 
pastor pergunta ao paroquiano acerca dos motivos de sua disposição para o suicídio. Recebe como resposta a informação de que ele estava pensando na possibilidade havia algum tempo. Tomas arrisca hipóteses para as motivações de Jonas: finanças, casamento, política, saúde etc. Sem ouvir nenhuma palavra, resolve o próprio pastor falar de suas motivações para continuar vivendo, a despeito das perdas que sofrera. Complica-se ainda mais, pois confessa sua falta de fé ou, noutros termos, sua crença ingênua num Deus paterno. Acaba por se autodenominar como "um sacerdote ignorante, infeliz e ansioso" (LUZ de inverno, 2019, 40’00”), por haver acreditado num mundo organizado por um Deus bondoso, que dava a ele, Tomas, um lugar central em toda a história. E que tudo havia se colocado de ponta-cabeça durante a Guerra Civil Espanhola, ocasião em que Tomas era pastor em Lisboa (Portugal). Acrescenta, ainda, que somente sua mulher o conhecera, de fato, em meio ao turbilhão da crise vocacional e existencial.

O que deveria ser um aconselhamento do sacerdote ao pescador, torna-se uma confissão do pastor ao paroquiano - numa inusitada inversão de papéis. Por fim, Tomas se desculpa e questiona:

Se Deus não existe... isso realmente faria alguma diferença? A vida se tornaria compreensível. Seria um alívio. E a morte seria a extinção da vida. O fim do corpo e do espírito. Crueldade, solidão e medo... todas estas coisas seriam claras e transparentes. O sofrimento é incompreensível, portanto, não existe explicação. Não existe um criador. Nenhum provedor da vida, nenhum desígnio." (LUZ de inverno, 2019, 41'34"-42’26”).

Jonas se retira, e a câmera fecha em primeiríssimo plano o rosto do pastor Tomas, enquanto a parede atrás dele vai clareando, como que por efeito de uma luz mais forte, sugerindo discursivamente a ideia de uma iluminação do pastor. No mesmo momento, exclama ele em voz alta: "Deus... por que me abandonastes?” (LUZ de inverno, 2019, 43'09”) - algo muito próximo do desamparo sentido por Cristo na cruz. A câmera se afasta progressivamente como num retorno ao ponto anterior (do qual começara a avançar), Tomas se vira para janela, de onde vem a luz, e fixa o olhar por instantes. Pouco depois, retorna ao altar da igreja, depara-se com Märta e, acometido por uma tosse, agacha-se e verbaliza: "Agora estou livre. Finalmente livre" (LUZ de inverno, 2019, 44'43").

O plano-sequência em que o pastor tenta salvar o pescador da falta de sentido resulta em alívio, pois Tomas se dá conta da própria descrença 
"Mais um domingo no vale das lágrimas": um ensaio 155 de análise fílmica (Luz de inverno, Ingmar Bergman, 1962)

e se liberta da dúvida em face do silêncio de Deus. Contudo, sua paz de espírito é imediatamente interrompida com a notícia de uma morte (ou teria sido a morte a portadora de um notícia?): o pescador havia se suicidado. Segue, então, o pastor para o local em que está o corpo de Jonas, numa das poucas cenas do filme em ambiente externo. Em plano aberto, vê-se o pastor olhando para o corpo de Jonas e para arma de fogo próximos a uma árvore e à beira de um rio, cuja correnteza é notada sonoramente (que não deixa de ser um tipo de trilha sonora do filme). O plano adotado pelo diretor, portanto, aponta para a morte como evento natural, mas a narrativa que a precede deixa claro ao espectador que a ideia de suicídio se concretizara. Também o fracasso de Tomas, em seu ofício de pastor, de certa forma, foi materializado: não conseguiu livrar seu paroquiano da angústia, nem lhe salvar a vida. Teria faltado o uso de uma palavra mais decisiva? A dúvida do pastor, nascida desde o primeiro diálogo com Jonas (ainda na presença de Karin), vai ficar sem resposta.

Mesmo que na forma de um acontecimento fortuito, não pode passar sem o devido registro outra cena: preparando-se para visitar Karin com a notícia da morte do marido dela, Tomas se encontra com um menino de 10 anos de idade, que, em pleno domingo, vai à sala de aula (na casa de Märta) para pegar uma revista ou algo assim. Num rápido diálogo com o pastor, confessa não querer fazer o catecismo, sem nem ao menos saber o porquê da falta de vontade ou desejo - a sugerir uma nova geração para a qual a formação religiosa vai se tornando irrelevante (e indiferente às razões dessa irrelevância) ${ }^{7}$.

Segue-se, ainda, a tarefa de comunicar o suicídio do pescador, em meio ao profundo sentimento de impotência quanto a oferecer à viúva alguma palavra de conforto. Ao receber a notícia, Karin emudece e se senta nos degraus da escada - além disso, recusa ouvir uma leitura bíblica. Olhando vagamente, verbaliza estar sozinha. Viúva e grávida do quarto filho, apresentase como mais uma personagem abandonada e sem esperança. Mais ainda, com a difícil missão de avisar às crianças da morte do próprio pai.

$\mathrm{Na}$ tarde daquele eterno domingo, Tomas chega a outra comunidade (Frostnäs) para a celebração do culto, e se depara com a igreja totalmente vazia. Estão à disposição dele somente os funcionários do culto (o organista

Por paralelismo ou comparação, pior ainda era a situação do padre de Bernanos (2011) e Bresson (DIÁRIO de um padre, s.d.), que inspira a construção de Tomas (como personagem): as crianças da catequese se organizam para o ridicularizar, fazendo-o parecer um trouxa. 
e o sacristão) e uma incansável Märta - que foi quem o conduziu, dirigindo o carro, à localidade. O sacristão Algot tem esperanças de que o badalar dos sinos possa convocar alguns fiéis para a celebração, mas ninguém aparece. E o filme termina com uma cena semelhante à inicial: o culto e os espaços vazios dentro do templo, ainda mais vazios na segunda igreja. Não por acaso, a câmera mostra o organista Frederik verificando as horas para calcular o tempo que lhe resta para findar sua tediosa atividade.

\section{Considerações finais}

Com o deslocamento que se deu na modernidade do lugar outrora ocupado por Deus na cultura, qual seja, do tecido social impregnado por sua presença, para zonas de relações na esfera da vida privada (ou para concepções ateístas de ver e estar no mundo), não podemos nem devemos entender o silêncio de Deus senão como metáfora da angústia humana em face da morte. Pois ela, a morte, classificada de variegadas formas, permanece no campo daquilo que é inexorável ao ser humano.

Irreparável... Irremediável... Irreversível... Irrevogável... Impossível de cancelar ou curar... O ponto sem retorno... O final... O derradeiro... o fim de tudo. Há um e apenas um evento ao qual se podem atribuir todos esses qualificativos na íntegra e sem exceção. Um evento que torna metafóricas todas as outras aplicações desses conceitos. O evento que lhes confere significado primordial - prístino, sem adulteração nem diluição. Esse evento é a morte. (BAUMAN, 2008, p. 44).

Ainda que seja simbolicamente um evento enorme, Bauman nos faz recordar que, em nossos tempos, é somente a morte de alguém que possamos chamar de "você" (alguém próximo, um semelhante) que nos convida à reflexão - de matiz filosófico, conforme mencionamos anteriormente sobre a experiência da morte, "de vez que me oferece uma pista daquela terminalidade e irrevogabilidade em que a morte - toda e qualquer -, e apenas a morte, consiste" (2008, p. 61). A morte da pessoa querida, cuja vida esteve interligada com a nossa, é também algo (de perda) irreversível e irreparável que toma conta de nós e nos consome. Em Luz de inverno, por exemplo, a vida de Tomas exala a morte de sua mulher. E está claro que nem todo mundo experimenta o luto - e o supera ou não - da mesma forma. Por óbvio, nem todo mundo morre com a morte do outro significante, há lutos que são bem feitos. 
Do geral para o particular, o grito ou suspiro do desamparo humano na modernidade foi compartilhado pela própria personagem Märta (ao ouvir, ajoelhada e dentro de uma igreja quase vazia, o badalar dos sinos da tradição): "Se pelo menos tivéssemos uma verdade para acreditar" (LUZ de inverno, 2019, 1:19’12”). Há um aparente medo de seguir adiante, sem um amor a quem confiar a vida. Os sons do passado - os sinos estão a tocar parecem uma bela melodia em forma de convite à paralisia da ação. Por que prosseguir, se no mundo há mais bombas do que as necessárias para destruir a humanidade toda? Jonas sentiu o desamparo fatal diante da falta de uma resposta que lhe desse sentido.

Segundo os pressupostos deste artigo, há um limite quanto a nossa discussão em torno da verdade - e da vida que vale a pena ser vivida. Aquela verdade, segundo Bernanos (2011), que só nos pode atravessar pela palavra, ela mesma, tão instável em sua plasticidade. Eis aqui a novidade de nosso artigo: não foi sem intenção que utilizamos duas vezes a expressão "viceversa" ao longo do texto. Na primeira, para designar a possibilidade da passagem da morte para a vida; e, na segunda, da descrença para a crença. Há uma inversão na ordem e na lógica das palavras que estão em relação, sem ingenuidade, não como mero discurso, pois o argumento, por coerência, vem de nossa própria análise.

O sacristão Albot, cuja palavra foi interrompida no início do filme, assume o discurso no final da história - e, enquanto executa com rigor (excessivo) suas tarefas, transmite ou prega a seu pastor uma mensagem que reputava ser urgente ${ }^{8}$, e não podia passar daquele domingo:

Uma vez lhe disse que minhas dores não me deixavam dormir à noite... e me sugeriu que eu lesse. [...] Para me distrair. Comecei a ler o Evangelho. Devo dizer que é um excelente sonífero... pelo menos de vez em quando. Agora estou na passagem da paixão de Cristo... e as dores pararam. Por isso, pensei em discutir com o senhor. Sinto que devo fazê-lo. A paixão de Cristo, Seu sofrimento. Não acha que é um equívoco enfatizar Seu sofrimento? [...] Enfatizar a dor física[?]. Não pode ter sido tão ruim. Posso parecer presunçoso... mas humildemente digo... que sofri tanta dor física quanto Jesus. E Seus sofrimentos foram breves. Duraram umas 4 horas, certo? Sinto que ele sofreu muito mais em outro aspecto. Talvez eu esteja errado. Mas pense em Getsêmani, pastor. Todos os discípulos de Cristo adormeceram. Eles não haviam entendido o sentido da última ceia. E quando os guardas chegaram,

O que justifica a longa transcrição na forma de citação a seguir. 
eles fugiram... e Pedro O negou. Cristo já conhecia seus discípulos há 3 anos. Eles conviviam dia e noite... mas nunca entenderam o que Ele pretendia. Eles O abandonaram, todos eles. Ele ficou totalmente sozinho. Isto deve ter sido um grande sofrimento. Perceber que ninguém o compreende. Ser abandonado quando precisa contar com alguém. Isto deve ser extremamente doloroso. Mas o pior ainda estava por vir. Quando Cristo foi pregado na cruz, em meio ao sofrimento... ele gritou: "Deus, meu Deus! Por que me abandonastes?" Ele gritou tal [sic] alto quanto podia. Ele achou que Seu pai o havia abandonado. Achou que tudo que havia pregado era mentira. Nos momentos que antecederam sua morte, Cristo teve dúvidas. Certamente, aquele deve ter sido seu maior sofrimento. Deus ficou em silêncio. (LUZ de inverno, 2019, 1:11'44”-1:15'17').

De fato, em Luz de inverno o discurso tem proeminência em relação à imagem. Ainda assim, quanto à análise fílmica (que nos auxilia na leitura do que nos diz o filme), a cena em questão está marcada por um jogo de luz e sombra, com a câmera fechada num rosto e em outro, alternadamente, cujos olhares não se entrecruzam. Os olhos do pastor estão como que direcionados ao nada, ou melhor, para dentro de si. Em primeiro plano, Algot segue sereno, ao passo que a testa de Tomas se mostra cada vez mais suada a cada corte. De novo, uma inversão: é o sacristão quem ensina ao mestre religioso da paróquia que a religião não pode ser um castelo construído para morarmos em segurança, pois, se assim constituída, seria ela a negação da vida - que é permeada pelo absurdo (PIEPER, 2017).

Na sequência do roteiro, o organista Frederik comemora a possibilidade de não haver culto - por absoluta falta de pessoas -, e fala diretamente a Märta que o pastor estava acabado (e acabando com a igreja) desde o tempo de sua viuvez, sugerindo a ela que o abandonasse e se mudasse para outra região. Quase concomitantemente, Tomas toma a decisão de iniciar o culto, após o toque dos sinos, ainda que estivessem com ele somente o sacristão, o organista e Märta. Algot sorri sutilmente, de modo satisfeito, ao perguntar para o pastor: "Vamos rezar a missa?" (Luz de inverno, 2019, 1:19’35”). Ato contínuo, acende as luzes elétricas -que, na opinião dele, atrapalham a devoção (que é favorecida pela luz de velas). Muita luz menos religião, parece fazer sentido o insight do sacristão nos tempos modernos. De sua parte, suspira agoniado Frederik, que se vê obrigado a cumprir, ao órgão, a parte que lhe cabe da liturgia.

Depois do ato cerimonial perante o altar, observado atentamente por Märta (aflita para saber qual seria a atitude de seu amado), o pastor Tomas 
"Mais um domingo no vale das lágrimas": um ensaio 159 de análise fílmica (Luz de inverno, Ingmar Bergman, 1962)

dirige as seguintes palavras à congregação, mas, principalmente, a si mesmo: "Santo, Santo, Santo, Senhor Deus do Universo. A terra proclama a Vossa glória” (LUZ de inverno, 2019, 1:20’42"-1:20’50”). Deus, outrora silente, agora se faz proclamar por toda Terra.

Passa-nos a impressão de que o pastor luterano (de Bergman) faz eco às últimas palavras do pároco católico da aldeia francesa, registradas pelo amigo que com ele esteve em seu leito de morte: "Que importa? Tudo é graça” (BERNANOS, 2011, p. 285). No filme de Bresson, o plano da cena dá destaque a uma cruz - a proeminência do objeto (LEMOS FILHO, 1992) -, envolta num misto de luz e sombra, com as palavras lidas pausadamente, sem exibição de nenhuma pessoa, nenhum rosto (DIÁRIO de um padre, s.d., 1:54'46"). Tudo é graça, conclui o padre diante de sua própria morte.

Daí não ser inoportuno considerarmos que Tomas, por sua vez, reencontra-se com o Cristo na cruz (aquela mesma imagem, a do crucifixo, que ele julgou ridícula no início da história), justamente por compartilharem a condição humana do desamparo advindo do silêncio de Deus em face da morte. Se há uma saída para a situação de torpor mortal, ela está propriamente na Terra (não no além) e no outro (não no transcendente): "Se há um Deus que se mostra ausente e se, no limite, não há Deus, a saída é assumir a relação com os outros. É justamente no esquecimento dessa questão do abandono de Deus que se pode encontrar um primeiro movimento no sentido de se encontrar a redenção" (PIEPER, p. 286, 2017).

Para Tomas, é vida que segue, de modo diferente ou não, pois a cena cortada mantém a narrativa em suspensão. E, assim, chega ao fim aquele longo domingo no vale das lágrimas.

\section{Referências}

ARIÈS, P. O homem diante da morte, v. II. Rio de Janeiro: Francisco Alves, 1981.

A TRILOGIA do silêncio. Direção: Ingmar Bergman. Brasil: Versátil Digital Filmes, 2019. 3 DVDs (281 $\mathrm{min})$.

AUMONT, J.; MARIE, M. A análise do filme. Lisboa: Edições Texto \& Grafia, 2009.

BAUMAN, Z. Medo líquido. Rio de Janeiro: Zahar, 2008.

BAUMAN, Z. O mal-estar da pós-modernidade. Rio de Janeiro: Zahar, 1998.

BERGMAN, I. Imagens. São Paulo: Martins Fontes, 1996.

BERnANOS, G. Diário de um pároco de aldeia. São Paulo: É Realizações, 2011. 
COMTE-SPONVILlE, A. Apresentação da filosofia. São Paulo: Martins Fontes, 2002.

DIÁRIO de um padre. Direção: Robert Bresson. Brasil: Cult Classic, s.d. 1 DVD (115min). HAN, B.-C. Sociedade do cansaço. 2 reimp. Petrópolis: Vozes, 2016.

KOVÁCS, M. J. Educação para morte: temas e reflexões. São Paulo: Casa do Psicólogo; FAPESP, 2003.

LEMOS FILHO, A. O cinema e o sagrado (segunda parte). Comunicarte, v. X, n. 16/17, p. 8-46, 1992.

LUZ de inverno. Direção: Ingmar Bergman. Brasil: Versátil Digital Filmes, 2019. 1 DVD (96 $\mathrm{min})$.

MARTIN, M. A linguagem cinematográfica. São Paulo: Brasiliense, 2007.

MEIRELES, M. V. C. O Silêncio de Deus: considerações sobre as relações entre cinema e religião a partir de Luz de Inverno. Mal-Estar e Sociedade, v. 12, n. 1, p. 38-50, 2017. Disponível em: https://revista.uemg.br/index.php/gtic-malestar/article/view/700/1954. Acesso em: 28 mai. 2021.

MELO, A. F. T. O que “dizem” os filmes sobre a morte? - ensaios de análise fílmica. 2013. Tese (Doutorado em Psicologia) - Instituto de Psicologia, Universidade de São Paulo. São Paulo, 2013. Disponível em: https://teses.usp.br/teses/disponiveis/47/47131/tde-08102013150427/pt-br.php. Acesso em: 26 maio. 2021.

METZ, C. A significação no cinema. 2 ed. São Paulo: Perspectiva, 1977.

PAULA, M. G. A crise de fé como ponto fundamental do filosofar: Bergman e Bresson. Interações, v. 7, n. 11, p. 99-111, jan.-jun. 2011. Disponível em: http://periodicos.pucminas. br/index.php/interacoes/article/view/6191. Acesso em: 16 mai. 2021.

PIEPER, Frederico. Diálogos possíveis. As ambiguidades da vida em Paul Tillich e Ingmar Bergman. Revista Eletrônica Correlatio, v. 16, n. 1, p. 259-289, jun. 2017.

TURNER, G. Cinema como prática social. São Paulo: Summus, 1997.

VANOYE, F.; GOLIOT-LÉTÉ, A. Ensaio sobre a análise fílmica. 5 ed. Campinas: Papirus, 1994.

Submetido em: 29-6-2021

Aceito em: 11-10-2021 